\title{
AOIR
}

Selected Papers of \#AoIR2021: The 22nd Annual Conference of the Association of Internet Researchers

Virtual Event / 13-16 Oct 2021

\section{“HAVE A GREAT, POSITIVE, BEAUTIFUL DAY!": GOOD MORNING MEMES AND THE CROSS-CULTURAL ARTICULATION OF VALUES}

\author{
Tommaso Trillò \\ Department of Communication and Journalism \\ The Hebrew University of Jerusalem
}

This paper adopts the lens of social media rituals to study a new incarnation of ritualized greetings: good morning memes. These are a popular yet under-studied form of ritualized greeting posted every morning by social media users across the global. Such memes feature text with a wish for the incoming day paired with elements such as flowers, food or animals. In this paper, I focus on the ways in which these memes construct values, broadly defined as guiding beliefs about the desirable. My analysis is based on a sample of 414 good morning memes posted to Instagram in English and Italian. I conducted a content analysis examining the posts for content (protagonist and background), the main values conveyed (e.g. achievement and self-efficacy, happiness and positivity), and their stance (serious or ironic). A preliminary analysis revealed strong consistency in the dataset. Overall, good morning memes embed the general mandate for "politeness" that infuses the communicative genre of greetings, transposing it in the meme format through impersonal messages and a saccharine aesthetic. Furthermore, the memes voice a shared core of values, namely: "Happiness and positivity" and "performative kindness." However, the English and Italian subsets also diverge in significant ways. The English language version of the meme upholds the value of "achievement and self-efficacy," possibly because of the influence of American values on globalized social media content. Conversely, the Italian-language version of the meme uses humor to pushback against the idea that the morning is a time to be energetic and productive.

Suggested Citation (APA): Trillò, T. (2021, October). "Have a Great, Positive, Beautiful Day!": Good Morning Memes and the Cross-Cultural Articulation of Values. Paper presented at AolR 2021: The 22nd Annual Conference of the Association of Internet Researchers. Virtual Event: AolR. Retrieved from http://spir.aoir.org. 